\title{
Magnetic hyperthermia of breast cancer cells and MRI relaxometry with dendrimer-coated iron-oxide nanoparticles
}

\author{
Marzieh Salimi 1,2@0, Saeed Sarkar ${ }^{1,2^{*}}$, Reza Saber ${ }^{2,3}$, Hamid Delavari $^{4}$, Ali Mohammad Alizadeh ${ }^{5}$ \\ and Hendrik Thijmen Mulder ${ }^{6}$ (D)
}

\author{
${ }^{*}$ Correspondence: \\ Sarkar@tums.ac.ir \\ ${ }^{1}$ Department of Medical \\ Physics and Biomedical \\ Engineering, Faculty \\ of Medicine, Tehran \\ University of Medical \\ Sciences, Tehran, P.O. \\ Box 1417613151, Iran \\ Full list of author information \\ is available at the end of the \\ article
}

\begin{abstract}
Background: Recently, some studies have focused on dendrimer nanopolymers as a magnetic resonance imaging (MRI) contrast agent or a vehicle for gene and drug delivery. Considering the suitable properties of these materials, they are appropriate candidates for coating iron-oxide nanoparticles which are applied in magnetic hyperthermia. To the best of our knowledge, the novelty of this study is the investigation of fourth-generation dendrimer-coated iron-oxide nanoparticles (G $\mathrm{G}_{4} @ \mathrm{IONPS}$ ) in magnetic hyperthermia and MRI.
\end{abstract}

Methods: IONPs were synthesized via co-precipitation and coated with the fourth generation $\left(\mathrm{G}_{4}\right)$ of polyamidoamine dendrimer. The cytotoxicity of $\mathrm{G}_{4} @ \mid \mathrm{ONPs}$ with different concentrations was assessed in a human breast cancer cell line $\left(\mathrm{MCF}_{7}\right)$ and human fibroblast cell line $\left(\mathrm{HDF}_{1}\right)$. Hemolysis and stability of $\mathrm{G}_{4} @$ lONPs were investigated, and in addition, the interaction of these particles with $\mathrm{MCF}_{7}$ cells was assessed by Prussian blue staining. Heat generation and specific absorption rate (SAR) were calculated from measurement and simulation results at 200 and $300 \mathrm{kHz} . \mathrm{MCF}_{7}$ and $\mathrm{HDF}_{1}$ cells were incubated with $\mathrm{G}_{4} @$ IONPs for $2 \mathrm{~h}$ and then put into the magnetic coil for $120 \mathrm{~min}$. Relaxometry experiments were performed with different concentrations of $\mathrm{G}_{4} @ \mid \mathrm{ONPs}$ with $\mathrm{T} 1$ - and $\mathrm{T} 2$-weighted MR images.

Results: The TEM results showed that $\mathrm{G}_{4} @$ IONPs were $10 \pm 4 \mathrm{~nm}$. The in vitro toxicity assessments showed that synthesized nanoparticles had low toxicity. The viability of $\mathrm{MCF}_{7}$ cells incubated with $\mathrm{G}_{4} @$ IONPs decreased significantly after magnetic hyperthermia. In addition, MR imaging revealed that $\mathrm{G}_{4} @$ @ONPs improved transverse relaxivity $(\mathrm{r} 2)$ significantly.

Conclusions: Our results encouraged the future application of G4@IONPs in magnetic hyperthermia and MR imaging.

Keywords: Magnetic hyperthermia, MRI, Iron-oxide nanoparticles, Dendrimer, Breast cancer

\section{Background}

Recently, magnetic hyperthermia is increasingly being used in cancer treatment due to its advantages over other treatments (Jiang et al. 2014). In magnetic hyperthermia, an alternating magnetic field (AMF) is utilized to heat magnetic nanoparticles (MNPs) such 
as iron-oxide nanoparticles (IONPs), which increases the tumor temperature by $3-7{ }^{\circ} \mathrm{C}$ (Pearce et al. 2013; Prasad et al. 2007). Samanta et al. assessed the thermoablation efficiency of protein-coated iron-oxide NPs ( $\operatorname{size}=12.1 \mathrm{~nm} \pm 1.6 \mathrm{~nm}$ ) in cultured HeLa cells incubated with MNPs $(4 \mathrm{mg} / \mathrm{ml})$ for $2 \mathrm{~h}$ followed by $45 \mathrm{~min}$ of AMF exposure $(400 \mathrm{kHz}$, $\left.6.3 \mathrm{kA} \mathrm{m}^{-1}, \mathrm{SAR}=36 \mathrm{~W} / \mathrm{g}_{\mathrm{Fe}}\right)$. Immediately after treatment, cytotoxicity was measured to show demolition of cancer cells due to MNPs heating (Samanta et al. 2008).

MRI has been applied as a common medical diagnostic instrument due to its noninvasive nature and topographic properties. This technique is based on the magnetic relaxation of water protons under an external magnetic field (Kojima et al. 2011). IONPs can also be used as MRI contrast agents because of their unique properties including high chemical activity, biocompatibility, and saturation magnetization (Kojima et al. 2011; Barick et al. 2012; Khot et al. 2013).

In this study, IONPs were coated with dendrimers, which are a promising category of coating materials and have attracted significant attention in recent years (Tajabadi et al. 2013). Indeed, dendrimers, compared to the other nanovectors including micelles and liposomes, whose properties are difficult to control, have tunable characteristics which make them attractive materials for biomedical applications (Tomalia et al. 2007). PAMAM dendrimers are hydrophilic, biocompatible, monodisperse, and high-branched three-dimensional macromolecules with void spaces in their internal structure (Mohammad and Yusof 2014; Wolinsky and Grinstaff 2008). On the other hand, dendrimer-based contrast agents possess sufficient binding sites to which numerous imaging, targeting, and therapeutic moieties can be conjugated (Longmire et al. 2008). In the 1990s, Lauterbur et al. demonstrated the feasibility of dendrimer-based MRI contrast agents for the first time in vascular imaging (Tomalia 2006). Chandra et al. indicated that dendrimers loaded with doxorubicin improved the efficiency of this drug for demolishing breast cancer cells and recommended this nanostructure for combined cancer therapies (Chandra et al. 2011). Given the importance of using coating materials with the capability of being used in theragnostic applications, dendrimers were selected as IONPs coating in this study.

To the best of our knowledge, no research has been performed on the application of $\mathrm{G}_{4} @ I O N P s$ in magnetic hyperthermia. This study was performed to investigate the efficiency of $\mathrm{G}_{4} @ I O N P s$ in magnetic hyperthermia of breast cancer cells and the potential of using G4@IONPs as an MRI contrast agent by determining the relaxivity of this nanostructure with MRI.

\section{Methods}

\section{Materials}

Ferric sulfate heptahydrate $\left(\mathrm{FeSO}_{4} \cdot 7 \mathrm{H}_{2} \mathrm{O}, 99 \% \mathrm{w} / \mathrm{w}\right)$, ferric chloride hexahydrate $\left(\mathrm{FeCl}_{3}\right.$, $\left.6 \mathrm{H}_{2} \mathrm{O}, 99 \% \mathrm{w} / \mathrm{w}\right)$, hydrochloric acid $(\mathrm{HCl}, 32 \% \mathrm{v} / \mathrm{v})$, ammonia solution $\left(\mathrm{NH}_{3}, 32 \% \mathrm{v} / \mathrm{v}\right)$, methanol $(99.9 \% \mathrm{v} / \mathrm{v}), 3$-aminopropyltriethoxysilane $\left[\mathrm{NH}_{2}\left(\mathrm{CH}_{2}\right)_{3}-\mathrm{Si}-\left(\mathrm{OCH}_{3}\right)_{3}\right.$, APTS], ethanol $(99.9 \% \mathrm{v} / \mathrm{v})$, methyl acrylate $(99.5 \% \mathrm{v} / \mathrm{v})$, methoxy-PEG and ethylenediamine (99\% v/v), Eagle's minimal essential medium (DEMEM), fetal bovine serum (FBS), and PenStrep were used in synthesis process and cell culture; all materials were purchased from Sigma-Aldrich (Germany). 


\section{Synthesis of IONPs and APTS-coated IONPs}

IONPs were synthesized via the co-precipitation method which is explained in our previous study (Salimi et al. 2018). Briefly, $0.84 \mathrm{~g}$ of $\mathrm{FeSO}_{4}$ and $1.22 \mathrm{~g}$ of $\mathrm{FeCl}_{3}$ were dissolved in $20 \mathrm{ml}$ deionized water followed by $30 \mathrm{~min}$ sonication. Then, $1 \mathrm{ml}$ of $2 \mathrm{M} \mathrm{HCl}$ was slowly added with vigorous stirring in a nitrogen atmosphere. After $2 \mathrm{~min}, 4.6 \mathrm{ml}$ ammonia was quickly added to the solution and stirring was continued for $1 \mathrm{~min}$. The black precipitate of IONPs was washed five times with distilled water and ethanol through magnetic decantation. To IONPs coating with APTS, $150 \mathrm{ml}$ ethanol was added to $25 \mathrm{ml}$ of $5 \mathrm{~g} \mathrm{l}^{-1}$ IONPs solution which was sonicated for $30 \mathrm{~min}$; after $20 \mathrm{~min}$ of sonication, $300 \mu \mathrm{l}$ of APTS was added to the mixture. Finally, the solution was stirred for $15 \mathrm{~h}$ at room temperature, and eventually, the resultant black precipitate was washed with ethanol three times (Khot et al. 2013).

\section{Surface coating of IONPs with dendrimer and PEGylation}

$10 \mathrm{ml}$ ethanol was added to the APTS@IONPs solution after $30 \mathrm{~min}$ sonication; subsequently, methyl acrylate/methanol solution $(20 \%, \mathrm{v} / \mathrm{v})$ was added $(50 \mathrm{ml})$ at $0{ }^{\circ} \mathrm{C}$ during the sonication for $1 \mathrm{~h}$ followed by stirring for $48 \mathrm{~h}$. Then, after washing the resultant solution with methanol, $15 \mathrm{ml}$ ethylenediamine/methanol (50\%, v/v) was added and the solution was sonicated for $3 \mathrm{~h}$ at $25^{\circ} \mathrm{C}$. This process was repeated to earn the fourth dendrimer generation $\left(\mathrm{G}_{4}\right)$. The final solution was washed several times with methanol and water by magnetic decantation or centrifugation (Khodadust et al. 2013).

Eventually, mPEG molecules (molecular weight of $4000 \mathrm{Da}$ ) were conjugated to the surface of amino groups of dendrimers. The applied mPEG mass was three times more than the mass of iron. The mPEG was dissolved in the ethanol solution and added to the $\mathrm{G}_{4} @ \mathrm{IONPs}$ solution followed by $18 \mathrm{~h}$ reflux.

\section{Characterization}

The morphology and size distribution of $\mathrm{G}_{4} @ I O N P s$ were studied by transmission electron microscopy (TEM) and the hydrodynamic size and surface potential were measured through dynamic light scattering (DLS) and zeta potential, respectively. Magnetic properties of IONPs and $G_{4} @ I O N P s$ were measured by vibrating sample magnetometer (VSM) at $300 \mathrm{~K}$ under the magnetic field up to $15 \mathrm{kOe}$. Furthermore, the crystalline phase of IONPs was confirmed by X-ray diffraction (XRD, $\lambda=0.15406 \mathrm{~nm}$ ) and G4 PAMAM bonds on the surface of IONPs was detected by Fourier-transform infrared spectroscopy (FTIR).

\section{Cytotoxicity assay}

MTT (3-[4,5-dimethylthiazol-2yl]-2,5-diphenyltetrazolium bromide) assay was used to determine the cytotoxicity of $\mathrm{G}_{4} @ \mathrm{IONPs}$ in $\mathrm{MCF}_{7}$ and $\mathrm{HDF}_{1}$ cell lines. Cells were incubated in 96-well plates at a cell density of $4 \times 10^{3}$ cells per well and cultured in DMEM supplemented with $10 \% \mathrm{FBS}$ and $1 \%$ PenStrep at $37{ }^{\circ} \mathrm{C}$ and $5 \% \mathrm{CO}_{2}$ for $24 \mathrm{~h}$. Subsequently, cells were washed twice with PBS and treated with serum-free culture media containing $\mathrm{G}_{4} @ I O N P s$ in concentrations of 1500, 1000, 500, 100, 10, 1, and 0 (control) 
$\mu \mathrm{g} / \mathrm{ml}$. After incubation for $24 \mathrm{~h}$, the culture media were removed, and $100 \mu \mathrm{l}$ of serumfree medium and $10 \mu \mathrm{l}$ of MTT solution were added to each well for $4 \mathrm{~h}$. Finally, $100 \mu \mathrm{l}$ of dimethyl sulfoxide (DMSO) was added; the absorbance of wells was measured using ELISA reader (Hiperion, microplate reader MPR4+) at $540 \mathrm{~nm}$ (Salimi et al. 2013).

\section{Hemolysis assay}

Blood samples from healthy male BALB/c mice were collected in heparin-coated tubes. The red blood cells (RBCs) were obtained by centrifuging the blood samples at $1500 \mathrm{rpm}$ for $5 \mathrm{~min}$ and removing the upper plasma. The RBCs were washed three times with sterile isotonic $0.9 \% \mathrm{NaCl}$ solution, and the purified $\mathrm{RBCs}$ were suspended in sterile isotonic $0.9 \% \mathrm{NaCl}$. The $\mathrm{RBC}$ suspension $(300 \mu \mathrm{l})$ was mixed with $1 \mathrm{ml}$ of 1000, 500, 250, 100, 50, and $10 \mu \mathrm{g} / \mathrm{ml}$ of $\mathrm{G}_{4} @ I O N P s$. All samples were incubated at $37^{\circ} \mathrm{C}$ for $2 \mathrm{~h}$ and then centrifuged for $2 \mathrm{~min}$ at $4000 \mathrm{rpm}$. Distilled water and isotonic $0.9 \% \mathrm{NaCl}$ were applied as positive and negative controls, respectively. The supernatant absorbance was measured at $540 \mathrm{~nm}$ using ELISA reader (Hiperion, microplate reader MPR4+) (Li et al. 2015). The hemolysis percentage was calculated using the following equation:

$$
\% \text { Hemolysis }=\frac{\mathrm{OD}_{\text {sample }}-\mathrm{OD}_{\text {negativecontrol }}}{\mathrm{OD}_{\text {positivecontrol }}-\mathrm{OD}_{\text {negativecontrol }}} \times 100 .
$$

\section{Stability of $\mathrm{G}_{4} @$ @IONPs}

The stability of $\mathrm{G}_{4} @ I O N P s$ was investigated by recording the change in turbidity in $50 \%$ FBS. $150 \mu \mathrm{l}$ of $\mathrm{G}_{4} @ \mathrm{IONPs}$ suspension $(100 \mu \mathrm{g} / \mathrm{ml})$ was added to $150 \mu \mathrm{l}$ of FBS in 96-well plates and incubated for different times up to $72 \mathrm{~h}$ at $37{ }^{\circ} \mathrm{C}$. After that, the absorbance of samples was measured at $405 \mathrm{~nm}$. A solution of $5 \%$ glucose was employed as a negative control (Li et al. 2015).

\section{Temperature-time curves}

The radiofrequency $(\mathrm{RF})$ absorption of $\mathrm{G}_{4} @ \mathrm{IONPs}$ was determined by establishing the AMF-specific absorption rate (SAR), which is defined as the amount of induced heat per unit mass of MNPs per unit of time $\left(\frac{\Delta T}{\Delta t}\right)$ (Wolinsky and Grinstaff 2008; Xia et al. 2009). A magnetic hyperthermia research system (LABA, HT-1000W, NATSYCO) with a frequency range of $100-400 \mathrm{kHz}$ was used. An Eppendorf microtube containing $\mathrm{G}_{4} @ I O N P s$ solution $(200 \mu \mathrm{l})$ was inserted inside the water-cooled magnetic induction copper coil (6 cm in diameter). The temperature rise was measured with a digital thermometer and plotted against time (temperature-time curve) at frequencies of 200 and $300 \mathrm{kHz}$ with a field intensity of $12 \mathrm{kA} / \mathrm{m}$. The SAR values were calculated using the following equation:

$$
\mathrm{SAR}=\left(\frac{1}{m_{\mathrm{Fe}}}\right) C\left[\frac{\Delta T}{\Delta t}\right]
$$


where $m_{\mathrm{Fe}}$ is the mass of iron in the sample, $C$ is the specific heat capacity of the sample, and $\left[\frac{\Delta T}{\Delta t}\right]$ is the initial slope of the temperature-time curve (Natividad et al. 2008, 2009).

The net temperature change was yield by the following equation:

$$
\Delta \mathrm{T}=\mathrm{T}_{\mathrm{n}}-\mathrm{T}_{0}
$$

where $T_{0}$ and $T_{\mathrm{n}}$ are initial temperature and temperature at the interval, respectively. The SAR was estimated from the initial and steepest part of the slope of the time-temperature curve. We determined the appropriate interval for calculating the slope by analyzing the plot of incremental temperature change and selecting the region with a constant first derivative of the heating rate. The temperature change was calculated over every interval (i.e., $T_{\mathrm{n}}-T_{\mathrm{n}-1}$ ), and the results were plotted versus heating time ( $t$ ) (Bordelon et al. 2011).

\section{Simulation of heat generation and transfer}

To verify the measurement results, simulation of heat generation due to magnetic hyperthermia was performed using COMSOL Multiphysics. The microtube, MNPs solution, and surrounding atmosphere were implemented to assess the heat transfer in a timetransient manner. Different heat transfer mechanisms were included in the simulations, e.g., heat transfer in fluids for the solution and surrounding air, and heat transfer in solids for the tube. Based on certain values of SAR for $1 \mathrm{ml}$ of $\mathrm{G}_{4} @ I O N P s$ suspension, heat generation and heat transfer rates were modeled as functions of time.

\section{Histochemistry analysis}

For Prussian blue staining, used to detect the presence of iron, $\mathrm{MCF}_{7}$ cells were incubated in a medium containing $\mathrm{G}_{4} @ \mathrm{IONPs}(500 \mu \mathrm{g} / \mathrm{ml})$ for $2 \mathrm{~h}$. Subsequently, cells were fixed with $4 \%$ formalin at room temperature for $20 \mathrm{~min}$ and washed with PBS, followed by the incubation with $10 \%$ potassium ferrocyanide in $10 \% \mathrm{HCl}(50 \%, \mathrm{v} / \mathrm{v})$ for $20 \mathrm{~min}$ (Samanta et al. 2008). $\mathrm{MCF}_{7}$ cells after $2 \mathrm{~h}$ incubation with 500, 250, 100, 50, and 0 (control) $\mu \mathrm{g} / \mathrm{ml} \mathrm{G}_{4} @ I O N P s$ were trypsinized and collected by centrifugation. The collected cells were lysed by $2 \mathrm{ml} 65 \%$ nitric acid. The amount of the nanoparticles cell uptake was quantified using inductively coupled plasma mass spectrometry (ICP-MS) (Varian Inc, Palo Alto, CA) and the resulting concentration was divided by counting the cell numbers.

\section{Magnetic hyperthermia in breast cancer and normal cells}

At $24 \mathrm{~h}$ after seeding $4 \times 10^{5}$ cells $\left(\mathrm{MCF}_{7}\right.$ and $\left.\mathrm{HDF}_{1}\right)$ in a $35 \mathrm{~mm}$ dish, cells were incubated with medium with/without the $\mathrm{G}_{4} @ I O N P s$ in a concentration of $500 \mu \mathrm{g} / \mathrm{ml}$ for $2 \mathrm{~h}$ at $37^{\circ} \mathrm{C}$. For hyperthermia treatment, these cells were put in the magnetic coil for $120 \mathrm{~min}(12 \mathrm{kA} / \mathrm{m}$ and $300 \mathrm{kHz})$, and control cells were left in the incubator at $37^{\circ} \mathrm{C}$. Immediately afterward, the viability of cells was assessed by MTT assay. 


\section{Apoptosis assay}

After hyperthermia condition, identifying of apoptotic cells was determined using in situ cell death detection kit (Roche, Mannheim, Germany) terminal uridine deoxynucleotidyl transferase dUTP nick end labeling (TUNEL) staining. Assay performed according to the manufacturer's protocol. Briefly, $\mathrm{MCF}_{7}$ cells were fixed by $4 \%$ paraformaldehyde for 10 min, permeabilized with $0.2 \%$ Triton X-100 for 2 min on ice, and incubated with a mixture of TUNEL reaction. Cells treated with $5 \%$ ethanol for positive apoptosis control. For negative apoptosis control, cells were induced only with label solution. Evaluation performed by an inverted fluorescent microscope.

\section{Relaxivity measurements of $\mathrm{G}_{\mathbf{4}} @$ @IONPs}

Relaxivity is a measure of the ability of a contrast agent to enhance the relaxation of adjacent hydrogen spins, which can improve contrast in MRI images (Barick et al. 2014). To assess the relaxivity of $\mathrm{G}_{4} @ I O N P s$, samples were prepared at different concentrations of $1,2,4,8,10,12,16$, and $20 \mu \mathrm{g} / \mathrm{ml}$ and placed in a plastic container. Longitudinal and transverse relaxation times $\left(T_{1}\right.$ and $\left.T_{2}\right)$ were measured by $3 \mathrm{~T}$ MRI scanner (Trio Tim/ SIEMENS, Munich, Germany). To measure $T_{1}, 6$ spin echoes (SE) images were acquired with an echo time (TE) of $12 \mathrm{~ms}$ and repetition times (TR) of 3000, 2000, 1000, 500, 250, and $100 \mathrm{~ms}$. To measure $T_{2}$, $32 \mathrm{SE}$ images were obtained with TR of $3000 \mathrm{~ms}$ and TE of 12-384 ms. The signal intensity (SI) of each concentration was determined via RadiAnt Dicom viewer software and calculated by Eqs. 4 and 5:

$$
\begin{aligned}
& \mathrm{SI}=S_{0}\left(1-\mathrm{e}^{\frac{-\mathrm{TR}}{T_{1}}}\right) \\
& \mathrm{SI}=S_{0} \mathrm{e}^{\frac{-\mathrm{TE}}{\mathrm{T}_{2}}},
\end{aligned}
$$

where $R_{1}$ and $R_{2}$ curves were obtained via logarithmic fitting to SI versus TR and TE curves, respectively, using the OriginPro 2016 software. Eventually, the relaxivity values $\left(r_{1}\right.$ and $\left.r_{2}\right)$ were estimated using a linear fit to $\mathrm{R}_{1}$ and $\mathrm{R}_{2}$ versus $\mathrm{G}_{4} @ \mathrm{IONPs}$ concentration curves, respectively. All sequences were acquired using a $280 \times 280 \mathrm{~mm}^{2}$ field of view (FOV), a resolution of $256 \times 230$ pixels, and slice thickness of $7 \mathrm{~mm}$.

To evaluate the in vivo capability of $\mathrm{G}_{4} @ I O N P s$, an MRI study was performed on animal models. BALB/c mice were intravenous injected with $0.2 \mathrm{ml} \mathrm{G}$ @ IONPs at Fe concentration of $1 \mathrm{mg} / \mathrm{ml}$. The MRI experiments were performed using a $3 \mathrm{~T}$ MRI scanner (MAGNETOM Prisma/SIEMENS, Munich, Germany) with a magnetic field intensity of $3 \mathrm{~T}$. The following parameters were adopted for obtaining in vivo MR images and signal intensity analysis in vivo: FOV $6 \times 6 \mathrm{~cm}$, matrix size $=256 \times 125$, slice thickness $4 \mathrm{~mm}$, TEs 41.6, 71, $113.6 \mathrm{~ms}$, and TR $2000 \mathrm{~ms}$.

\section{Statistical analysis}

All data were expressed as mean \pm SD and one-way ANOVA was used for statistical analysis. $P<0.05$ was considered statistically significant. 


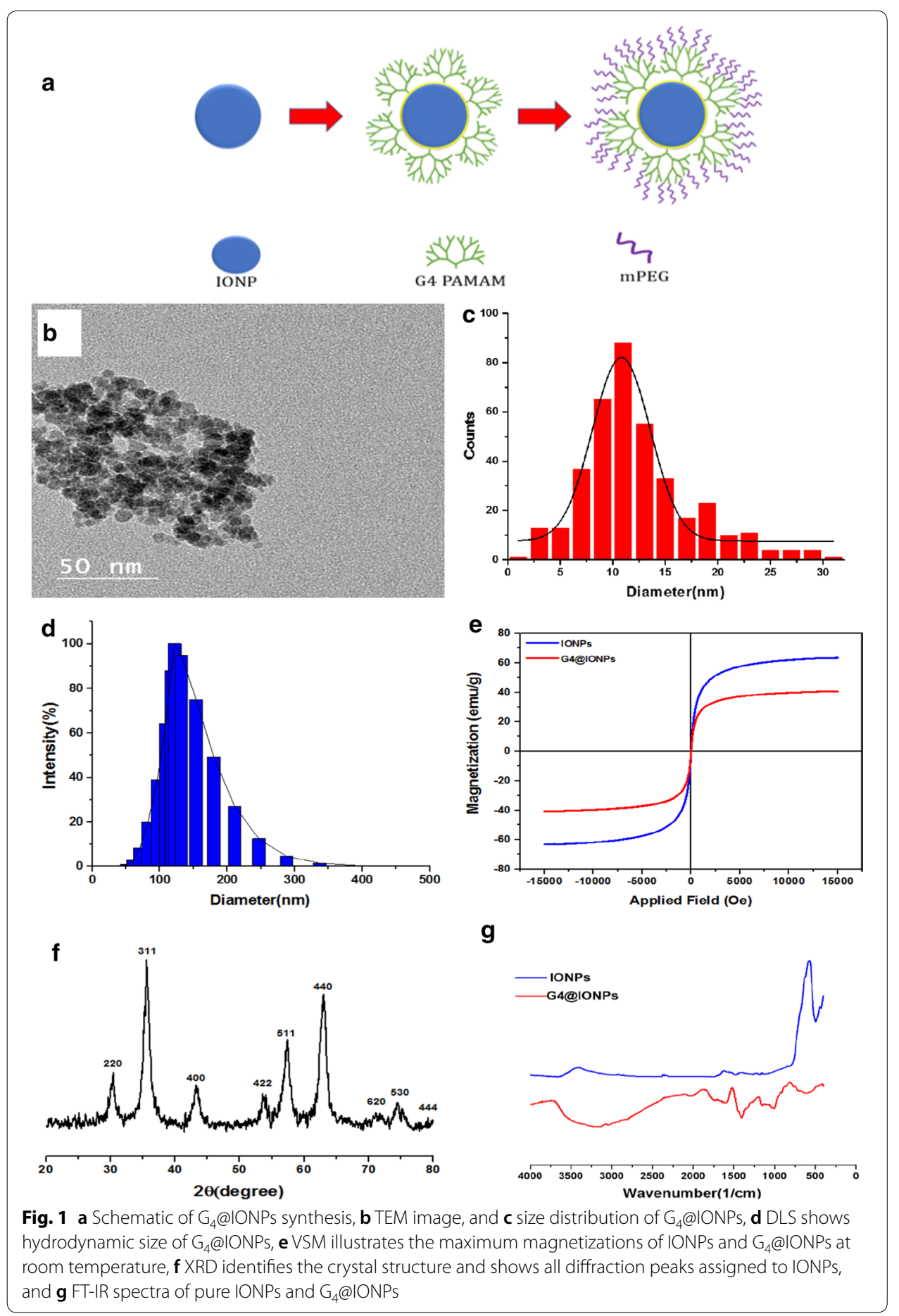

\section{Results}

\section{Characterization of $\mathrm{G}_{4} @$ IONPs}

The schematic of G4@IONPs synthesis is shown in Fig. 1a. The size of $\mathrm{G}_{4} @ \mathrm{IONPs}$ was $10 \pm 4 \mathrm{~nm}$ measured by TEM (Fig. 1b, c). Hydrodynamic size of $\mathrm{G}_{4} @ \mathrm{IONPs}$ was $120 \mathrm{~nm}$ as measured by DLS, and surface potential of these NPs was $+35 \mathrm{mV}$ at $\mathrm{PH}=7$ and 
$25^{\circ} \mathrm{C}$ (Fig. 1d). M-H curve without any hysteresis loop was measured above the blocking temperature by VSM and maximum magnetization for IONPs and G4@IONPs at room temperature were 63.4 and $40.6 \mathrm{emu} \mathrm{g}^{-1}$, respectively (Fig. 1e). Results of XRD indicated that all diffraction peaks could be assigned to $\mathrm{Fe}_{3} \mathrm{O}_{4}$ without any impurities (Fig. 1f). The XRD pattern did not change by coating the NPs with PAMAM dendrimers (Khodadust et al. 2013). In FTIR spectra, the presence of the $\mathrm{Fe}_{3} \mathrm{O}_{4}$ core could be detected by the strong peaks between 408 and $673 \mathrm{~cm}^{-1}$; as well as the magnetite $\mathrm{Fe}-\mathrm{O}$ group bond observed at $570 \mathrm{~cm}^{-1}$, corresponding to the intrinsic stretching vibration of the metal at the tetrahedral site (Fe tetra-O) (Julian JM, Brezinski DR. An infrared spectroscopy atlas for the coatings industry 1991). The broad peak at $3444 \mathrm{~cm}^{-1}$ exhibited the bending mode of free $\mathrm{NH}_{2}$ groups present at APTS (Yamaura et al. 2004). The peaks of $-\mathrm{CO}-\mathrm{NH}-$ bonds were detected at 1490, 1570, and $1620 \mathrm{~cm}^{-1}$ (Fig. 1g) (Tsubokawa and Takayama 2000).

\section{Colloidal stability (aggregation) of $\mathrm{G}_{4} @$ IONPs}

It is imperative to consider that the colloidal stability of $\mathrm{G}_{4} @ I O N P s$ should be investigated before MRI applications. The hydrodynamic size maintained in a narrow range by DLS measurement after at least 28 days (almost 1 month), as shown in Fig. 2a. There was no sign of aggregation and flocculation or subsidence after 28 days of storage (Fig. 2b).

\section{Cytotoxicity assay}

The MTT assay was performed to investigate cytotoxic effect of $\mathrm{G}_{4} @ \mathrm{IONPs}$ on $\mathrm{MCF}_{7}$ and HDF1 cell lines at concentrations of 1500, 1000, 500, 100, 10, $1 \mu \mathrm{g} / \mathrm{ml}$ and 0 (control). The results clearly indicated that $\mathrm{G}_{4} @ I O N P s$ had no significant cytotoxicity at concentrations of $500 \mu \mathrm{g} / \mathrm{ml}$ and lower. At 1000 and $1500 \mu \mathrm{g} / \mathrm{ml}$, however, the viability of both cell lines decreased significantly (for $\mathrm{MCF}_{7}: 63 \%$ and 61\%; for $\mathrm{HDF}_{1}: 65 \%$ and 59\%, respectively) (Fig. 3a).

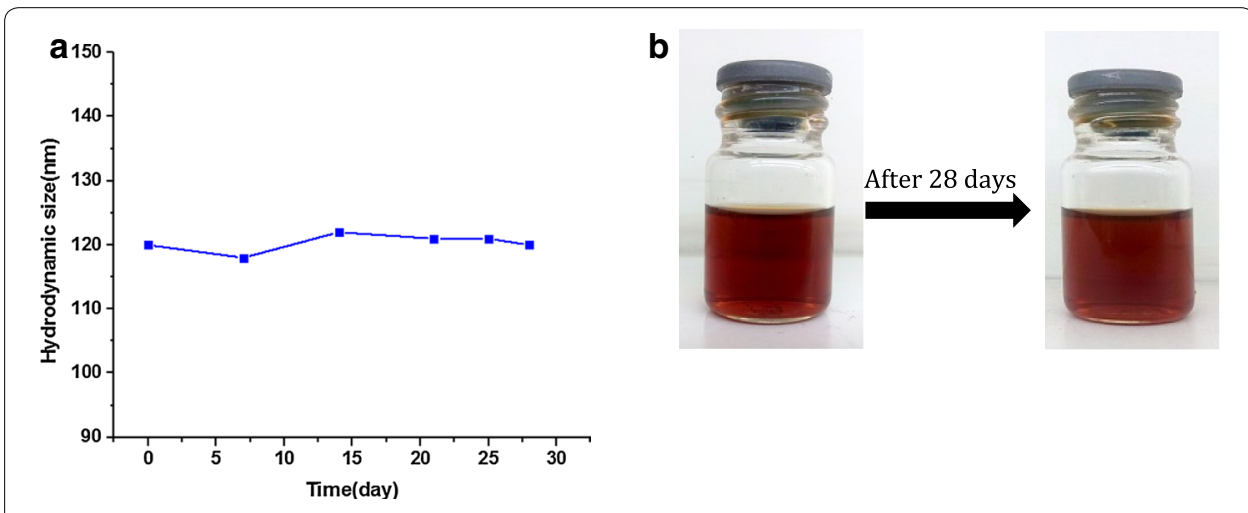

Fig. 2 a Hydrodynamic sizes of $\mathrm{G}_{4} @ \mid$ IONPs in aqueous solution as a function of storage time. b Time evolution of the sedimentation photographs of freshly prepared $\mathrm{G}_{4} @ \mid$ IONPs solution (left) and the solution after 28 days 

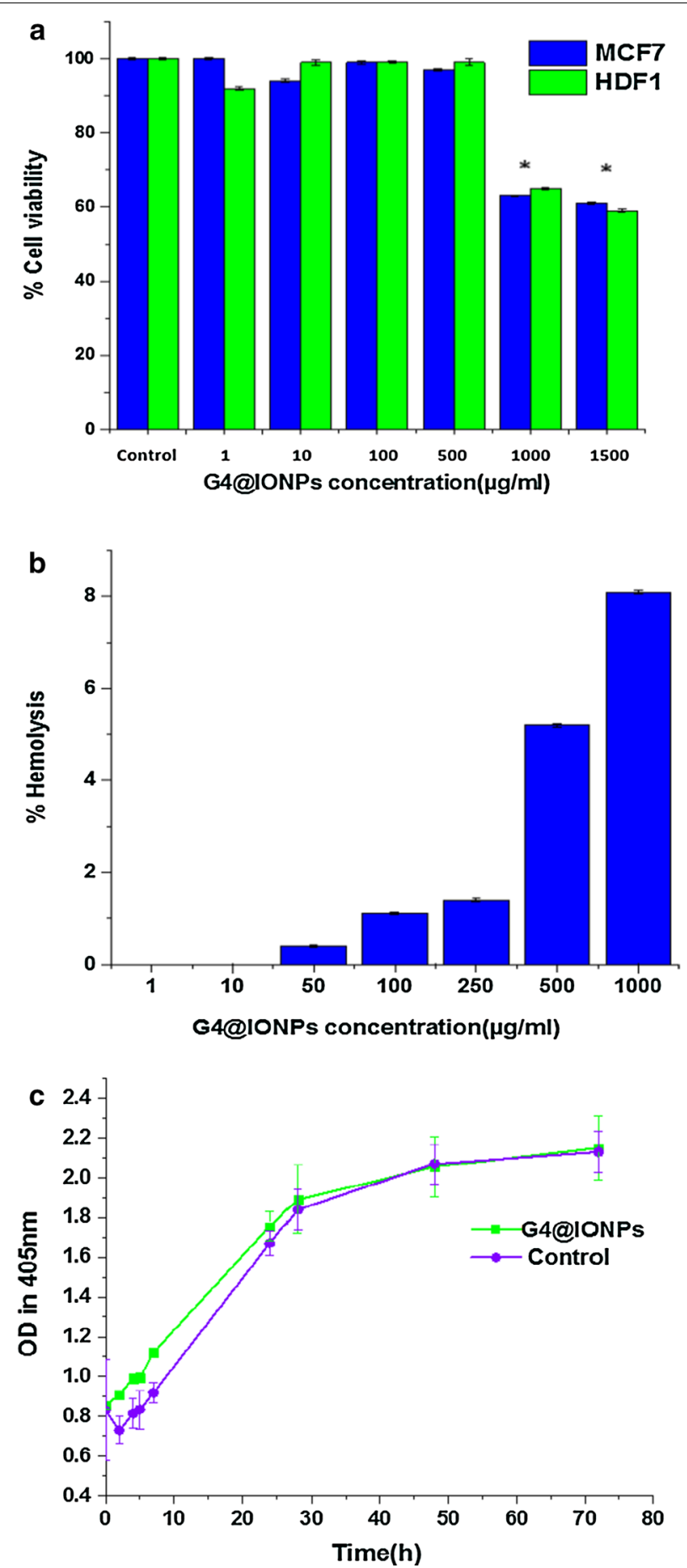

Fig. 3 a Cytotoxicity of $G_{4} @ \mid O N P s$ in $M C F_{7}$ and $H_{D F}$ cells $\left({ }^{*} P<0.05\right)$. The cytotoxic effect at concentrations of 1000 and $1500 \mu \mathrm{g} / \mathrm{ml}$ is significant in both cell lines. $\mathbf{b}$ Hemolysis assay was fulfilled to assess the effect of $\mathrm{G}_{4} @ \mid$ IONPs on RBCs. c No significant increase in turbidity of $\mathrm{G}_{4} @$ @IONPs suspension was detected after different incubation times 

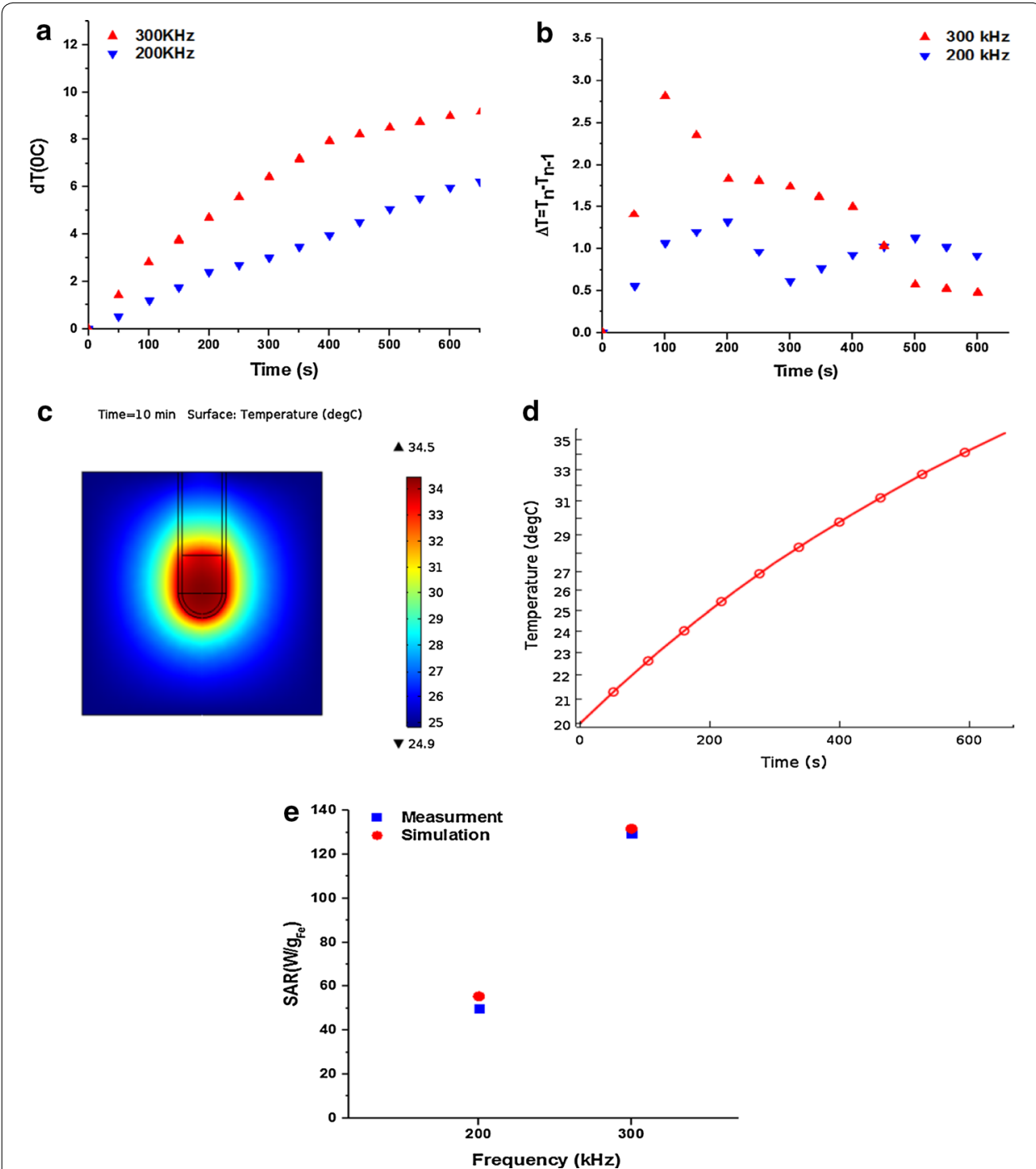

Fig. 4 a Temperature-time curves at 200 and $300 \mathrm{kHz}$. b Incremental temperature changes, $T_{n}-T_{n-1}$ over time. c Temperature distribution in the cross section of the model structure. $\mathbf{d}$ Simulated temperaturetime curve at $300 \mathrm{kHz}$ after $10 \mathrm{~min}$. e SAR values of the measurements and numerical analysis results at frequencies of 200 and $300 \mathrm{kHz}$

\section{Hemolysis and stability assessments}

Hemolysis assay was performed to assess the effect of $\mathrm{G}_{4} @ I O N P s$ on RBCs (Feng et al. 2014). The outcomes showed that $\mathrm{G}_{4} @ \mathrm{IONPs}$ at all concentrations did not have any hemolysis effect; the highest hemolysis activity was only $8.1 \%$ at $1000 \mu \mathrm{g} / \mathrm{ml}$ (Fig. 3b).

To investigate the stability of $\mathrm{G}_{4} @ I O N P s$ in a biological environment, the turbidity assay was performed via measuring the turbidity changes of $\mathrm{G}_{4} @ I O N P s$ suspension in FBS. No significant difference in turbidity of $\mathrm{G}_{4} @ I O N P s$ and control suspensions was detected over the different incubation times; as the turbidity changes in both suspensions were similar after $72 \mathrm{~h}$ of incubation (Fig. 3c). 

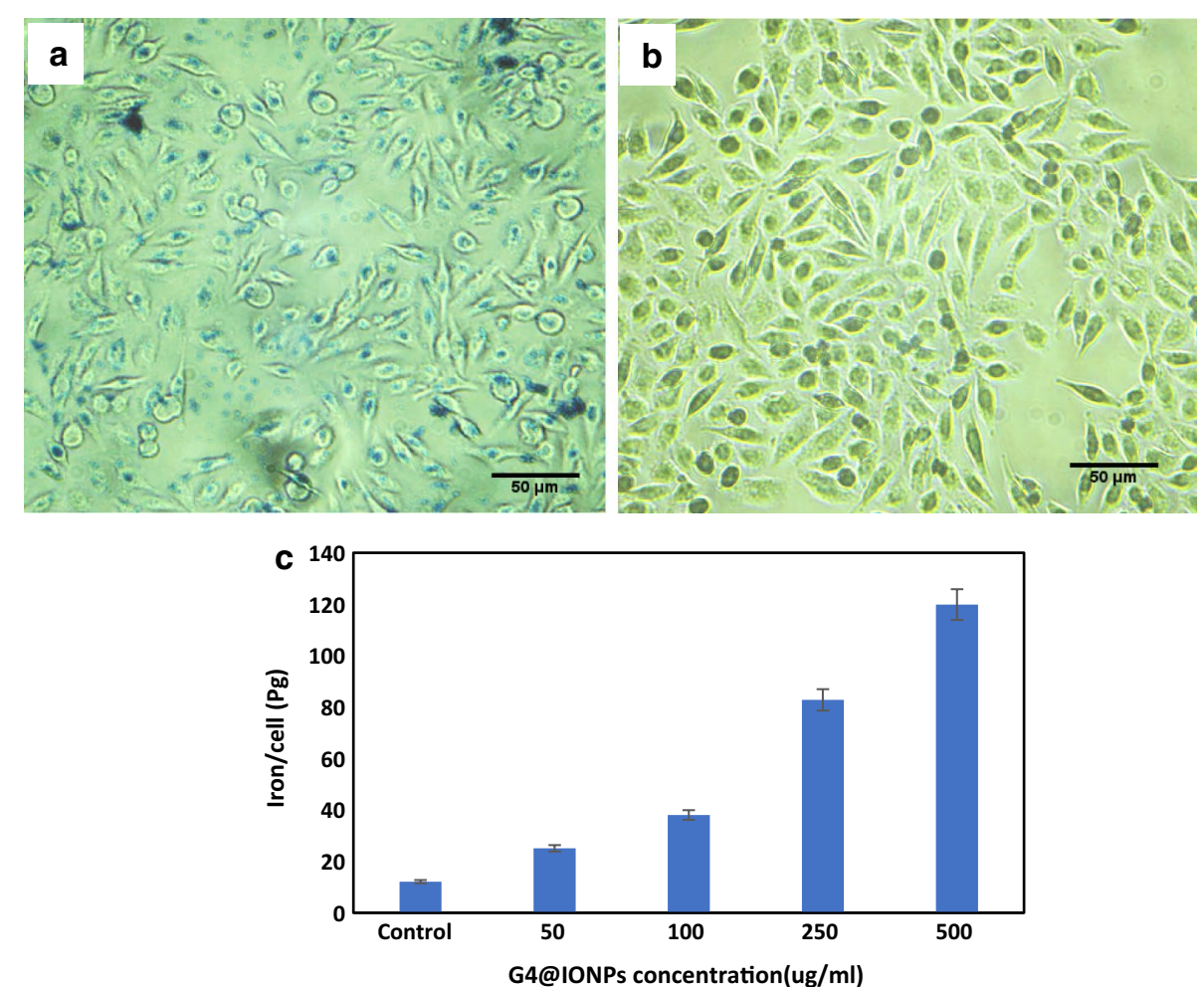

Fig. $5 \mathrm{MCF}_{7}$ cells incubated $\mathbf{a}$ with and $\mathbf{b}$ without (control) $\mathrm{G}_{4} @ \mid \mathrm{ONPs}$ followed by Prussian blue staining. $\mathbf{c}$ ICP-MS of different concentrations of $\mathrm{G}_{4} @$ IONPs

\section{Temperature-time curves and simulation}

Figure 4a illustrates temperature-time curves at 200 and $300 \mathrm{kHz}$ during AMF exposure. The incremental heating curve was drawn, and the time interval with a constant nonzero value was used to find the area in the temperature-time curve with a constant slope (Fig. 4b); since in area, there was not any temperature decay in the sample. The temperature distribution in the cross section of the model structure and temperature-time curve at $300 \mathrm{kHz}$ after $10 \mathrm{~min}$ is shown in Fig. 4c, d. The SAR calculated from measurements at 200 and $300 \mathrm{kHz}$ were 49.8 and $129.3 \mathrm{~W} / \mathrm{g}_{\mathrm{Fe}}$, respectively; the results were compared to the calculated SAR values in a simulation. The SAR values of the measurements were in a good agreement with the numerical analysis results (Fig. 4e).

\section{Internalization of $\mathrm{G}_{\mathbf{4}} @$ IONPs into cells}

Cell internalization of $\mathrm{G}_{4} @ \mathrm{IONPs}$ assessed by Prussian blue staining illustrated a high density of iron inside the $\mathrm{MCF}_{7}$ cells after $2 \mathrm{~h}$ incubation with $\mathrm{G}_{4} @ \mathrm{IONPs}$. The iron appeared as the blue precipitate in the cytoplasm (Fig. 5a, b). The results of ICP-MS showed that higher amount of iron $\left(119.8 \pm 3.5\right.$ pg) was taken up in higher $\mathrm{G}_{4} @ I O N P s$ concentration $(500 \mu \mathrm{g} / \mathrm{ml})$ (concentration-dependent). After identical sample preparation in the control, $12.1 \pm 2.7 \mathrm{pg}$ iron per cell could be detected. In the case of 50, 100, and $200 \mu \mathrm{g} / \mathrm{ml}$ of G4@IONPs, the numbers were 25,38 , and $82.8 \mathrm{pg} /$ cell, respectively (Fig. 5c). 

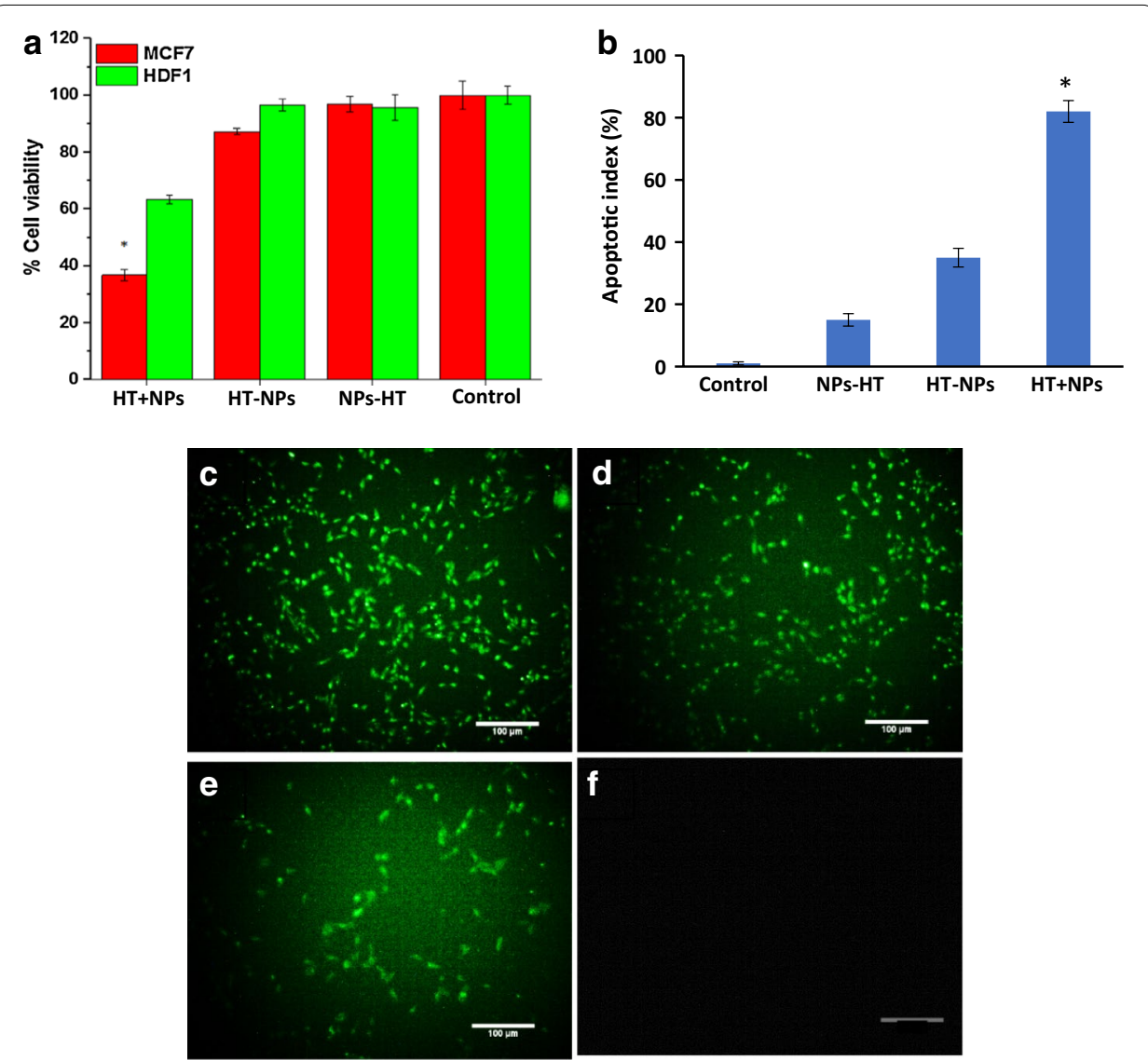

Fig. 6 a MCF7 and HDF1 cells' viability percentage after magnetic hyperthermia $\left({ }^{*} P<0.05\right)$; $\mathbf{b}$ apoptotic index $\left({ }^{*} P<0.05\right)$; TUNEL staining illustrated the apoptotic $\mathrm{MCF}_{7}$ cells in groups of: $\mathbf{c} H T+N P s \mathbf{d} H T-N P s$ e NPs-HT, and f control

\section{Cell viability affected by magnetic hyperthermia}

Immediately after magnetic hyperthermia $(\mathrm{HT})$, the viability of $\mathrm{MCF}_{7}$ and $\mathrm{HDF}_{1}$ cells was assessed in all groups (HT + NPs, HT - NPs, NPs $-\mathrm{HT}$, and control) by MTT assay. Cell viability percentage in the HT + NPs group decreased significantly $(36.7 \pm 2 \%)$, while the viability in other groups did not significantly decrease compared with control group $\left(96.8 \pm 2.3 \%\right.$ and $87.3 \pm 1.12 \%$, respectively). The viability of $\mathrm{HDF}_{1}$ cells cultured with $\mathrm{G}_{4} @ \mathrm{IONPs}$ did not decrease significantly due to AMF exposure (63.5 $\left.\pm 1.5 \%\right)$ (Fig. 6a).

\section{TUNEL assay}

Results of TUNEL assay showed the apoptosis of breast cancer cells immediately after magnetic hyperthermia in all groups (HT + NPs, HT - NPs, NPs $-\mathrm{HT}$, and control) (Fig. 6b). The results indicated apoptotic cells in HT + NPs were higher than that in other groups (82\%), while the fewer apoptosis was seen in groups of HT - NPs and NPs - HT (35\% and 15\%, respectively) (Fig. 6c-f). 

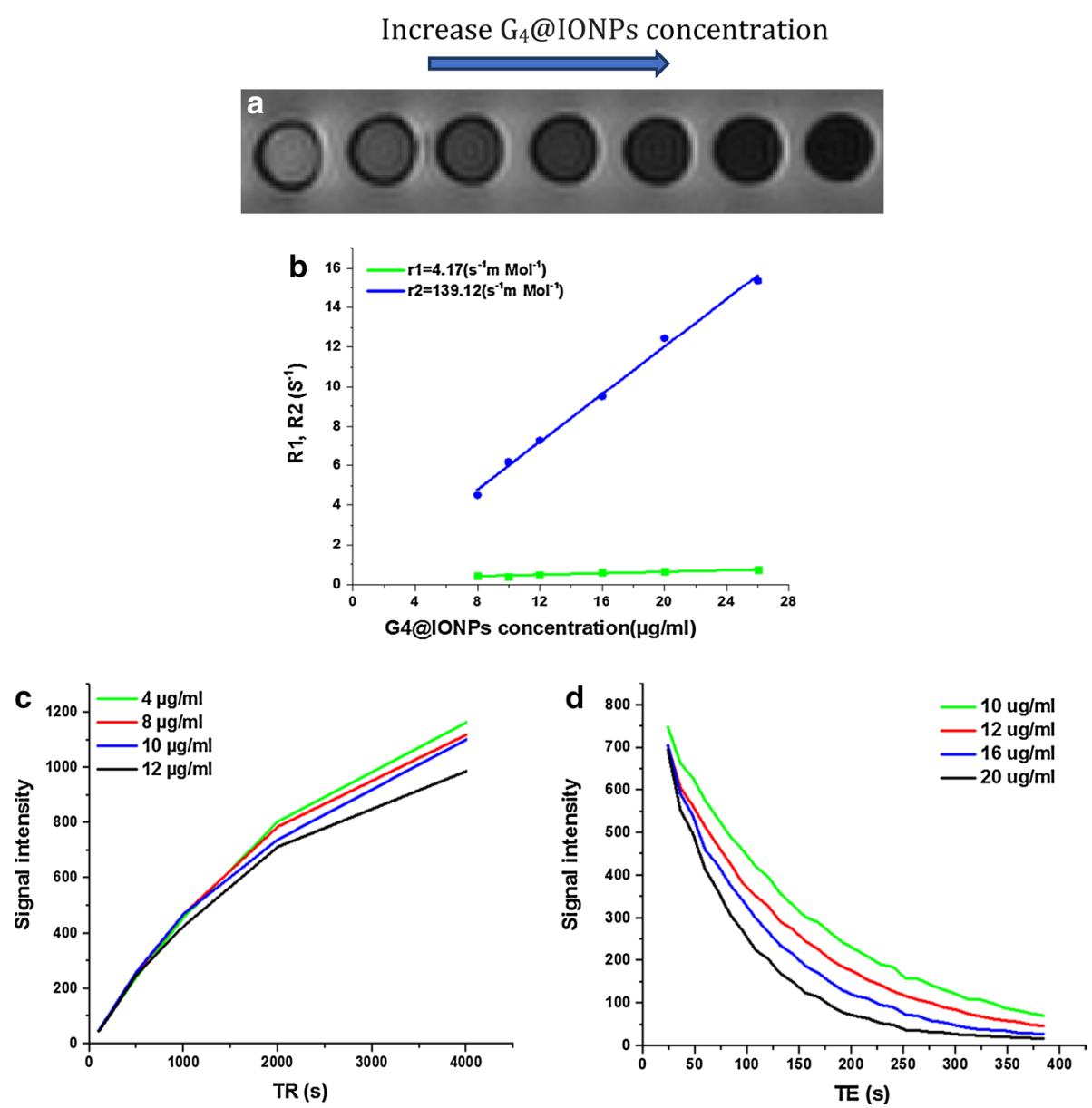

Fig. 7 a $T_{2}$-weighted MR images of $G_{4} @ I O N P s$ as a function of IONPs concentration, $\mathbf{b}$ relaxation rates $\left(R_{1}, R_{2}\right)$ versus concentration of $\mathrm{G}_{4} @ \mid \mathrm{ONPS}, \mathbf{c}$ increasing the $\mathrm{SI}$ versus TRs at different concentrations of $\mathrm{G}_{4} @ \mid \mathrm{ONPs}$, and d decreasing the $\mathrm{SI}$ versus TEs at different concentrations of $\mathrm{G}_{4} @$ IONPs

\section{MRI relaxometry and in vivo images}

Multi-echo SE images of $\mathrm{G}_{4} @ I O N P s$ showed decreasing signal intensity with increasing iron concentration (Fig. 7a). Indeed, the signal loss was more in higher iron concentrations because of shortening $\mathrm{T}_{2} \cdot \mathrm{R}_{1}$ and $\mathrm{R}_{2}$ relaxation curves versus $\mathrm{G}_{4} @ I O N P s$ concentration are depicted in Fig. 4b. Longitudinal $\left(r_{1}\right)$ and transverse $\left(r_{2}\right)$ relaxivities extracted from $R_{1}$ and $R_{2}$ curves were $4.17 \mathrm{~s}^{-1} \mathrm{Mm}^{-1}$ and $139.12 \mathrm{~s}^{-1} \mathrm{Mm}^{-1}$, respectively (Fig. $5 \mathrm{~b}$ ). Due to the $\mathrm{T}_{1}$ effect, signal curves versus TRs increased by decreasing $\mathrm{G}_{4} @ \mathrm{IONPs}$ concentration (Fig. 7c), while signal curves versus different TEs decreased with increasing the $\mathrm{G}_{4} @ I O N P \mathrm{I}^{\prime}$ concentration due to $\mathrm{T}_{2}$ relaxation time (Fig. $7 \mathrm{~d}$ ).

The capability of $\mathrm{G}_{4} @ I$ IONPs to visualize liver tissues was evaluated in male BALB/c mice. As shown in Fig. 8A, we acquired MR images with different TEs before, 10 and 60 min after intravenous injection. The $\mathrm{G}_{4} @ I O N P s$ darkened the MR images of liver with an intravenous injection after 10 and 60 min compared with that before injection; in addition, SI decreased with increasing the TE. It could also be seen that $60 \mathrm{~min}$ after injection of $\mathrm{G}_{4} @ I O N P s$, the liver images became substantially darker (more signal 


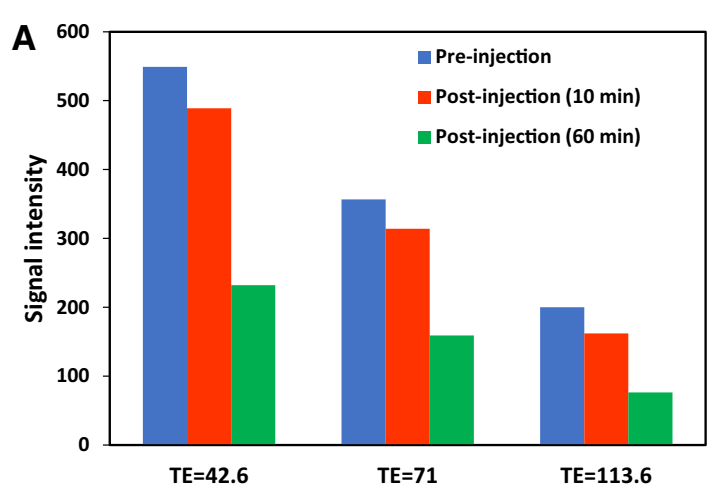

B
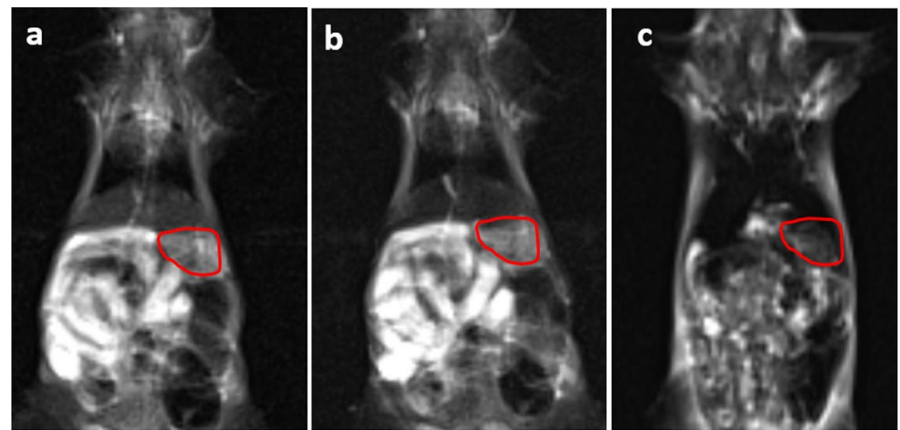

Fig. 8 A In vivo MR signal intensity of liver (TR = 2000 and different TEs) before, 10 and 60 min after intravenous injection of $\mathrm{G}_{4} @$ @INPs; $\mathbf{B}$ In vivo MR images of BALB/C mice (a) before, and after (b) 10 min and (c) 60 min intravenous injection of $\mathrm{G}_{4} @ \mid \mathrm{ONPs}(\mathrm{TR}=2000$, $\mathrm{TE}=71)$. The red contours show the liver tissue

intensity) in comparison with acquisition at 10 min post-injection ( $\mathrm{SI}=232$ versus 489 at $\mathrm{TE}=42.6)$, as shown in Fig. 8B (a, b, and c).

\section{Discussion}

The aim of this study was to investigate the application of $\mathrm{G}_{4} @ \mathrm{IONPs}$ in magnetic hyperthermia of $\mathrm{MCF}_{7}$ cancer cells and also to assess their feasibility as an MRI contrast agent. The $\mathrm{G}_{4} @ I O N P s$ were synthesized by co-precipitation and coated with $\mathrm{G}_{4}$ PAMAM dendrimer by a stepwise method. The characteristics of $\mathrm{G}_{4} @ I O N P s$ are important in determining their behavior in biomedical applications. TEM image showed that the size of $\mathrm{G}_{4} @ \mathrm{IONPs}$ was $10 \pm 4 \mathrm{~nm}$ with a positive surface charge of $+35 \mathrm{mV}$ (cationic) which can be effective on NPs uptake into cultured cells (Mecke et al. 2005).

The cell internalization was assessed by Prussian blue staining. The qualitative results showed that only $2 \mathrm{~h}$ after incubation, $\mathrm{G}_{4} @ \mathrm{IONPs}$ could enter the $\mathrm{MCF}_{7}$ cytoplasm, demonstrated by the blue spots in Fig. 5a. Hong et al. studied the interactions of PAMAM dendrimers and KB and Rat2 cell membranes (Hong et al. 2006). Their results showed that these polymers induced the formation of transient, nanoscale holes in living cells which allowed a significantly increased exchange of materials across the cell membrane. The authors claimed that the size of the polymers did not seem to markedly affect their ability to induce hole formation in the membranes. Furthermore, the architecture (sphere-like) of PAMAM polymers was effective for hole formation and 
increasing membrane permeability. Seib et al. also assessed the effect of generation $\left(\mathrm{G}_{2}-\right.$ $\mathrm{G}_{4}$ ) of PAMAM dendrimer on the endocytic capture and intracellular entrance by flow cytometry (Seib et al. 2007). They showed that all the cationic polymers were internalized via endocytosis, with maximum uptake for cationic $G_{4}$ PAMAM.

In general, MNPs heating in magnetic hyperthermia are due to three independent mechanisms including hysteresis loss, Brownian and Néel relaxation (Deatsch and Evans 2014; Mamiya and Jeyadevan 2011). The Brownian mode represents the rotational friction component in a given suspending medium. As the whole particle oscillates towards the magnetic field, the suspending medium opposes this rotational motion resulting in heat generation. The Néelian relaxation represents the rotation of the individual magnetic moments towards the alternating field (Rosensweig 2002).

When MNPs are exposed to an AMF, the magnetic moments tend to align in the direction of the field; in MNPs exhibiting hysteresis, domain walls can then move in the presence of an applied magnetic field; as a result, many single domains combine and create larger domains (domain growth). This shifting of domain walls produces the heat and continues until the point of magnetic saturation (Etheridge et al. 2012). Considering the VSM result, the $\mathrm{G}_{4} @ I O N P s$ did not have any hysteresis loop, meaning that the heating was only due to Brownian motion and Néelian relaxation (Deatsch and Evans 2014).

The hydrodynamic diameter was larger than that measured by TEM that might be because of two main reasons; first, the scattering of small particles varies strongly with particle radius in DLS and also the signal of larger particles can still overwhelm the signal of smaller ones. The second reason is that the techniques based on light scattering like DLS require a higher concentration of NPs solution which is more likely to lead to aggregation. Consequently, these aggregated NPs have a disproportionate influence on the analytical signal (Kim et al. 2014; Domingos et al. 2009). The colloidal stability results showed that there was not any aggregation or change in hydrodynamic diameter of $\mathrm{G}_{4} @$ IONPs after 28 days; it revealed that these MNPs had great colloidal stability which is a prerequisite for biomedical applications.

Furthermore, the hydrodynamic diameter $\left(V_{\mathrm{H}}\right)$ is crucial in Brownian relaxation time $\left(\mathrm{\tau}_{B}\right): \mathrm{\tau}_{B}=3 \eta V_{\mathrm{H}} / K_{B} \mathrm{~T}$, where $\eta$ is the viscosity of medium, $K_{\mathrm{B}}$ is the Boltzmann constant, and $T$ is the temperature (Rosensweig 2002). Indeed, the amount of heat generated due to Brownian relaxation depends inversely on hydrodynamic size (Deatsch and Evans 2014).

The application of IONPs in magnetic hyperthermia depends on the heating efficiency of these particles which is quantified as SAR. In our study, temperature rising measurements were performed at frequencies of 200 and $300 \mathrm{kHz}$ and a field intensity of $12 \mathrm{kA} / \mathrm{m}$. There are several parameters which affect induced SAR, including size, coating, aggregation of MNPs, frequency, and intensity of AMF (Li et al. 2015). SAR calculated from heat measurements was 49.8 and $129.3 \mathrm{~W} / \mathrm{g}_{\mathrm{Fe}}$ at 200 and $300 \mathrm{kHz}$, respectively; basically, SAR increases with increasing frequency of AMF (Kalber et al. 2005). The simulated SAR values were in a good agreement with measurements. The temperature rising curve at $300 \mathrm{kHz}$ had a plateau at approximately $400 \mathrm{~s}$, which meant a thermal equilibrium between the MNPs sample and the environment was reached at this time. As the plateau after $400 \mathrm{~s}$ in the simulation was not as pronounced as in the 
measurements, this could be due to thermal insulation and leakage of generated heat from sample to environment.

The MTT assay revealed that the cytotoxicity of $\mathrm{G}_{4} @ I O N P s$ was negligible at concentrations of $500 \mu \mathrm{g} / \mathrm{ml}$ and below. This could be due to the dendrimer coating and PEGylation, which made IONPs more biocompatible (Kojima et al. 2011). As mentioned before, dendrimers with cationic surface groups tend to interact with the lipid bilayer, increase the permeability, and decrease the integrity of the biological membrane. This causes the leakage of cytosolic proteins such as luciferase and lactate dehydrogenase and finally leads to the cell lysis (Mecke et al. 2005; Chen et al. 2004).

In a similar study, varying concentrations of ([G4]-PGLSA-OH)2-PEG3400 were incubated for 0.5 or $2 \mathrm{~h}$ with HT-29 human colon cancer cells. No cytotoxic effects were observed (Morgan et al. 2003). Jevprasesphant et al. studied the cytotoxicity of PAMAM dendrimers in Caco-2 cells; the results showed that anionic or half generation dendrimers had significantly lower toxicity than the cationic ones (Jevprasesphant et al. 2003).

Stability in the biological media is one of the crucial properties of IONPs in biomedical applications, since this is directly related to their diagnostic and therapeutic characteristic such as circulation time (Montazerabadi et al. 2015). In this study, to provide stabilized $\mathrm{G}_{4} @ I O N P s, \mathrm{mPEG}_{4000}$ coating was used, which possessed several advantages in aqueous solution (Longmire et al. 2008). The results indicated that the turbidity of $\mathrm{G}_{4} @$ IONPs suspension after $72 \mathrm{~h}$ was equivalent to the turbidity of control suspension (FBS); the optical density (OD) enhancement of $\mathrm{G}_{4} @ \mathrm{IONPs}$ suspension could be the result of instability of FBS solution, considering the increasing of FBS turbidity over the time.

The viability of $\mathrm{MCF}_{7}$ cells treated with $\mathrm{G}_{4} @ \mathrm{IONPs}$ was reduced significantly after AMF exposure $(P<0.05)$; the concentration of $\mathrm{G}_{4} @ \mathrm{IONPs}$ used in in vitro experiments was $500 \mu \mathrm{g} / \mathrm{ml}$, which had shown no any cytotoxic effect. TUNEL outcomes also confirmed the MTT results and in a way that apoptotic cancer cells in HT + NPs group was significantly higher than that in control group $(P>0.05)$. The viability of $\mathrm{HDF}_{1}$ cells cultured with $G_{4} @ I O N P s$ did not decrease significantly due to AMF exposure $(P>0.05)$. This could be because of that normal cells are less sensitive to the magnetic hyperthermia than cancer cells (Oei et al. 2017).

It is worthful to compare our result with other studies outcomes in which other hyperthermia methods like photothermal and microwave-induced photodynamic therapy were used. Magnetic hyperthermia is not the only localized hyperthermia modality using NPs. Li et al. studied photothermal ablation of cervical cancer HeLa cells with copper sulfide (CuS) nanoparticles and near-infrared (NIR) laser beam at $808 \mathrm{~nm}$. Their results showed that the photothermal destruction of HeLa cells occurred in a laser doseand NP-concentration-dependent manner ( $\mathrm{Li}$ et al. 2010). In another study, Yao et al. presented microwave-induced photodynamic therapy and applied copper cysteamine $(\mathrm{Cu}-\mathrm{Cy}) \mathrm{NPs}$ as a new type of photosensitizer. The outcomes revealed that microwave activation of $\mathrm{Cu}-\mathrm{Cy}$ method could significantly demolish rat osteosarcoma cell line (UMR 106-01) in both in vitro and in vivo studies (Yao et al. 2016). In photodynamic therapy, other types of photosensitizer were investigated such as graphitic-phase carbon nitride $\left(\mathrm{g}-\mathrm{C}_{3} \mathrm{~N}_{4}\right)$ quantum dots (QDs). The results of live/dead staining and flow cytometry in Chu et al. study showed that g-C3N4 QD-based photodynamic therapy could effectively kill cancer cells and promoted tumor cell death (Chu et al. 2017). 
Our experimental data clearly indicated that $\mathrm{G}_{4} @ I O N P s$ had the ability to increase $r_{2}$ to $139.12 \mathrm{~s}^{-1} \mathrm{mMol}^{-1}$. Indeed, IONPs create a magnetic field around themselves and, thereby, generate small field inhomogeneities in the external magnetic field. Thus, $T_{2}$ relaxivity time decreases due to the rapid dephasing of the spins ( $\mathrm{Li}$ et al. 2013). The liver MR signal became progressively weaker post-intravenous injection of $\mathrm{G}_{4} @ I O N P s$ when compared to that of the control mice before injection. The results indicated that $G_{4} @$ IONPs can be used as an MRI contrast agent.

\title{
Conclusion
}

The current study indicated that $\mathrm{G}_{4} @ I O N P s$ are promising therapeutic agents for magnetic hyperthermia of breast cancer cells; in addition, MR-imaging results showed that the synthesized nanocomposite is a capable MRI contrast agent for $\mathrm{T}_{2}$-weighted imaging, both in vitro and in vivo.

\begin{abstract}
Abbreviations
MRI: magnetic resonance imaging; $G_{4} @ I O N P s:$ fourth-generation dendrimer-coated iron-oxide nanoparticles; $G_{4}$ : fourth generation; PAMAM: polyamidoamine; SAR: specific absorption rate; NPs: nanoparticles; MNPs: magnetic nanoparticles; VSM: vibrating sample magnetometer; TEM: transmission electron microscopy; DLS: dynamic light scattering; XRD: X-ray diffraction; DMSO: dimethyl sulfoxide; RBCs: red blood cells; FBS: fetal bovine serum; ICP-MS: inductively coupled plasma mass spectrometry; SE: spin echoes; TE: echo time; TR: repetition times; FOV: field of view; SI: signal intensity; $V_{H}$ : hydrodynamic diameter; AMF: alternating magnetic field; $\tau_{\mathrm{B}}$ : Brownian relaxation time; OD: optical density; NIR: near-infrared; QDs: quantum dots.
\end{abstract}

\section{Authors' contributions}

MS conducted the experiments and wrote the first version of paper, SS supervised the experiments and writing the paper, RS assisted in the magnetic hyperthermia experiments, and HD helped in nanoparticle synthesis and characterization, AMA assisted in cell culture, and HTM assisted in editing the paper. All authors read and approved the final manuscript.

\section{Author details}

Department of Medical Physics and Biomedical Engineering, Faculty of Medicine, Tehran University of Medical Sciences, Tehran, P.O. Box 1417613151, Iran. ${ }^{2}$ Research Center for Science and Technology in Medicine, Tehran University of Medical Sciences, Tehran, Iran. ${ }^{3}$ Department of Medical Nanotechnology, School of Advanced Technologies in Medicine, Tehran University of Medical Sciences, Tehran, Iran. ${ }^{4}$ Department of Materials Science and Engineering, Tarbiat Modares University, Tehran, Iran. ${ }^{5}$ Cancer Research Center, Tehran University of Medical Sciences, Tehran, Iran. ${ }^{6}$ Department of Radiation Oncology, Erasmus Medical Center Cancer Institute, Rotterdam, The Netherlands.

\section{Acknowledgements}

The authors would like to thank Prof. Mohammad Ali Oghabian for his kind help in this study.

\section{Competing interests}

The authors declare that they have no competing interests.

\section{Availability of data and materials}

Not applicable.

\section{Ethics approval and consent to participate}

All applicable Tehran University of Medical Sciences guidelines for the care and use of animals were followed. This article does not contain any studies with human participants performed by any of the authors.

\section{Funding}

This study was funded by Tehran University of Medical Sciences (Grant Number 28169).

\section{Publisher's Note}

Springer Nature remains neutral with regard to jurisdictional claims in published maps and institutional affiliations.

Received: 31 March 2018 Accepted: 26 September 2018

Published online: 08 October 2018

\section{References}

Barick KC, Singh S, Jadhav NV, Bahadur D, Pandey BN, Hassan PA. pH-responsive peptide mimic shell cross-linked magnetic nanocarriers for combination therapy. Adv Func Mater. 2012;22(23):4975-84. 
Barick K, Singh S, Bahadur D, Lawande MA, Patkar DP, Hassan P. Carboxyl decorated $\mathrm{Fe}_{3} \mathrm{O}_{4}$ nanoparticles for MRI diagnosis and localized hyperthermia. J Colloid Interface Sci. 2014;418:120-5.

Bordelon DE, Cornejo C, Grüttner C, Westphal F, DeWeese TL, Ivkov R. Magnetic nanoparticle heating efficiency reveals magneto-structural differences when characterized with wide ranging and high amplitude alternating magnetic fields. J Appl Phys. 2011;109(12):124904.

Chandra S, Dietrich S, Lang H, Bahadur D. Dendrimer-doxorubicin conjugate for enhanced therapeutic effects for cancer. J Mater Chem. 2011;21(15):5729-37.

Chen H-T, Neerman MF, Parrish AR, Simanek EE. Cytotoxicity, hemolysis, and acute in vivo toxicity of dendrimers based on melamine, candidate vehicles for drug delivery. J Am Chem Soc. 2004;126(32):10044-8.

Chu X, Li K, Guo H, Zheng H, Shuda S, Wang X, et al. Exploration of graphitic- $\mathrm{C}_{3} \mathrm{~N}_{4}$ quantum dots for microwave-induced photodynamic therapy. ACS Biomater Sci Eng. 2017;3(8):1836-44.

Deatsch AE, Evans BA. Heating efficiency in magnetic nanoparticle hyperthermia. J Magn Magn Mater. 2014;354:163-72.

Domingos RF, Baalousha MA, Ju-Nam Y, Reid MM, Tufenkji N, Lead JR, et al. Characterizing manufactured nanoparticles in the environment: multimethod determination of particle sizes. Environ Sci Technol. 2009;43(19):7277-84.

Etheridge M, Manuchehrabadi N, Franklin R, Bischof J. Superparamagnetic iron oxide nanoparticle heating: a basic tutorial. in: Nanoparticle Heat Transfer and Fluid Flow. CRC Press; 2012. p. 97-121.

Feng W, Nie W, He C, Zhou X, Chen L, Qiu K, et al. Effect of pH-responsive alginate/chitosan multilayers coating on delivery efficiency, cellular uptake and biodistribution of mesoporous silica nanoparticles based nanocarriers. ACS Appl Mater Interfaces. 2014;6(11):8447-60.

Hong S, Leroueil PR, Janus EK, Peters JL, Kober M-M, Islam MT, et al. Interaction of polycationic polymers with supported lipid bilayers and cells: nanoscale hole formation and enhanced membrane permeability. Bioconjug Chem. 2006;17(3):728-34

Jevprasesphant R, Penny J, Jalal R, Attwood D, McKeown N. D'emanuele A. The influence of surface modification on the cytotoxicity of PAMAM dendrimers. Int J Pharm. 2003;252(1-2):263-6.

Jiang Q, Zheng S, Hong R, Deng S, Guo L, Hu R, et al. Folic acid-conjugated $\mathrm{Fe}_{3} \mathrm{O}_{4}$ magnetic nanoparticles for hyperthermia and MRI in vitro and in vivo. Appl Surf Sci. 2014;307:224-33.

Julian JM, Brezinski DR. An infrared spectroscopy atlas for the coatings industry. 1991

Kalber TL, Smith CJ, Howe FA, Griffiths JR, Ryan AJ, Waterton JC, et al. A longitudinal study of R2* and R2 magnetic resonance imaging relaxation rate measurements in murine liver after a single administration of 3 different iron oxide-based contrast agents. Invest Radiol. 2005;40(12):784-91.

Khodadust R, Unsoy G, Yalcın S, Gunduz G, Gunduz U. PAMAM dendrimer-coated iron oxide nanoparticles: synthesis and characterization of different generations. J Nanopart Res. 2013;15(3):1488.

Khot V, Salunkhe A, Thorat N, Ningthoujam R, Pawar S. Induction heating studies of dextran coated $\mathrm{MgFe}_{2} \mathrm{O}_{4}$ nanoparticles for magnetic hyperthermia. Dalton Trans. 2013;42(4):1249-58.

Kim H-A, Seo J-K, Kim T, Lee B-T. Nanometrology and its perspectives in environmental research. Environ Health Toxicol. 2014;29:1-9.

Kojima C, Turkbey B, Ogawa M, Bernardo M, Regino CA, Bryant LH Jr, et al. Dendrimer-based MRI contrast agents: the effects of PEGylation on relaxivity and pharmacokinetics. Nanomed Nanotechnol Biol Med. 2011;7(6):1001-8.

Li Y, Lu W, Huang Q, Li C, Chen W. In vitro photothermal ablation of tumor cells with CuS nanoparticles. Nanomedicine. 2010;5(8):1161-71.

Li L, Jiang W, Luo K, Song H, Lan F, Wu Y, et al. Superparamagnetic iron oxide nanoparticles as MRI contrast agents for non-invasive stem cell labeling and tracking. Theranostics. 2013;3(8):595.

$\mathrm{Li}$ T, Shen $\mathrm{X}$, Chen Y, Zhang C, Yan J, Yang H, et al. Polyetherimide-grafted $\mathrm{Fe}_{3} \mathrm{O}_{4} @ \mathrm{SiO}_{2}$ nanoparticles as theranostic agents for simultaneous VEGF siRNA delivery and magnetic resonance cell imaging. Int J Nanomed. 2015;10:4279.

Longmire M, Choyke PL, Kobayashi H. Dendrimer-based contrast agents for molecular imaging. Curr Top Med Chem. 2008:8(14):1180-6.

Mamiya $\mathrm{H}$, Jeyadevan B. Hyperthermic effects of dissipative structures of magnetic nanoparticles in large alternating magnetic fields. Sci Rep. 2011;1:157.

Mecke A, Majoros IJ, Patri AK, Baker JR, Banaszak Holl MM, Orr BG. Lipid bilayer disruption by polycationic polymers: the roles of size and chemical functional group. Langmuir. 2005a;21(23):10348-54.

Mecke A, Lee D-K, Ramamoorthy A, Orr BG, Banaszak Holl MM. Synthetic and natural polycationic polymer nanoparticles interact selectively with fluid-phase domains of DMPC lipid bilayers. Langmuir. 2005b;21 (19):8588-90.

Mohammad F, Yusof NA. Doxorubicin-loaded magnetic gold nanoshells for a combination therapy of hyperthermia and drug delivery. J Colloid Interface Sci. 2014;434:89-97.

Montazerabadi AR, Oghabian MA, Irajirad R, Muhammadnejad S, Ahmadvand D, Delavari HH, et al. Development of goldcoated magnetic nanoparticles as a potential MRI contrast agent. NANO. 2015;10(04):1550048.

Morgan MT, Carnahan MA, Immoos CE, Ribeiro AA, Finkelstein S, Lee SJ, et al. Dendritic molecular capsules for hydrophobic compounds. J Am Chem Soc. 2003;125(50):15485-9.

Natividad E, Castro M, Mediano A. Accurate measurement of the specific absorption rate using a suitable adiabatic magnetothermal setup. Appl Phys Lett. 2008;92(9):093116.

Natividad E, Castro M, Mediano A. Adiabatic vs. non-adiabatic determination of specific absorption rate of ferrofluids. J Magn Magn Mater. 2009;321(10):1497-500.

Oei A, Vriend L, Krawczyk P, Horsman M, Franken N, Crezee J. Targeting therapy-resistant cancer stem cells by hyperthermia. Int J Hyperth. 2017;33(4):419-27.

Pearce J, Giustini A, Stigliano R, Hoopes PJ. Magnetic heating of nanoparticles: the importance of particle clustering to achieve therapeutic temperatures. J Nanotechnol Eng Med. 2013;4(1):011005.

Prasad N, Rathinasamy K, Panda D, Bahadur D. Mechanism of cell death induced by magnetic hyperthermia with nanoparticles of $\mathrm{Y}-\mathrm{Mn} \times \mathrm{Fe}_{2}-\times \mathrm{O}_{3}$ synthesized by a single step process. J Mater Chem. 2007;17(48):5042-51.

Rosensweig RE. Heating magnetic fluid with alternating magnetic field. J Magn Magn Mater. 2002;252:370-4.

Salimi M, Shahbazi-Gahrouei D, Karbasi S, Kermani S, Razavi S. Effect of extremely low-frequency $(50 \mathrm{~Hz})$ field on proliferation rate of human adipose-derived mesenchymal stem cells. J Isfahan Med School. 2013;31 (232):439-55 
Salimi M, Sarkar S, Fathi S, Alizadeh AM, Saber R, Moradi F, et al. Biodistribution, pharmacokinetics, and toxicity of dendrimer-coated iron oxide nanoparticles in BALB/c mice. Int J Nanomed. 2018;13:1483.

Samanta B, Yan H, Fischer NO, Shi J, Jerry DJ, Rotello VM. Protein-passivated $\mathrm{Fe}_{3} \mathrm{O}_{4}$ nanoparticles: low toxicity and rapid heating for thermal therapy. J Mater Chem. 2008;18(11):1204-8.

Seib FP, Jones AT, Duncan R. Comparison of the endocytic properties of linear and branched PEls, and cationic PAMAM dendrimers in B16f10 melanoma cells. J Control Release. 2007;1 17(3):291-300.

Tajabadi M, Khosroshahi ME, Bonakdar S. An efficient method of SPION synthesis coated with third generation PAMAM dendrimer. Colloids Surf A. 2013;431:18-26.

Tomalia DA. Dendrimers as multi-purpose nanodevices for oncology drug delivery and diagnostic imaging. Nanomed Nanotechnol Biol Med. 2006;4(2):309.

Tomalia DA, Reyna L, Svenson S. Dendrimers as multi-purpose nanodevices for oncology drug delivery and diagnostic imaging. London: Portland Press Limited; 2007.

Tsubokawa N, Takayama T. Surface modification of chitosan powder by grafting of 'dendrimer-like' hyperbranched polymer onto the surface. React Funct Polym. 2000;43(3):341-50.

Wolinsky JB, Grinstaff MW. Therapeutic and diagnostic applications of dendrimers for cancer treatment. Adv Drug Deliv Rev. 2008:60(9):1037-55.

Xia T, Kovochich M, Liong M, Meng H, Kabehie S, George S, et al. Polyethyleneimine coating enhances the cellular uptake of mesoporous silica nanoparticles and allows safe delivery of siRNA and DNA constructs. ACS Nano. 2009;3(10):3273-86

Yamaura M, Camilo R, Sampaio L, Macedo M, Nakamura M, Toma H. Preparation and characterization of (3-aminopropyl) triethoxysilane-coated magnetite nanoparticles. J Magn Magn Mater. 2004;279(2-3):210-7.

Yao M, Ma L, Li L, Zhang J, Lim RX, Chen W, et al. A new modality for cancer treatment-nanoparticle mediated microwave induced photodynamic therapy. J Biomed Nanotechnol. 2016;12(10):1835-51.

- fast, convenient online submission

- thorough peer review by experienced researchers in your field

- rapid publication on acceptance

- support for research data, including large and complex data types

- gold Open Access which fosters wider collaboration and increased citations

- maximum visibility for your research: over 100M website views per year

At BMC, research is always in progress.

Learn more biomedcentral.com/submissions 